\title{
Impact of Employee Motivation on Job Satisfaction With Respect To Corporate Social Responsibility and Rewards
}

\author{
Muhammad Yousaf Khan \\ MS Scholar, National College of Business Administration \& Economics \\ Bahawalpur Campus, Pakistan
}

Muhammad Rizwan

Lecturer, Department of Management Sciences,

The Islamia University of Bahawalpur, Pakistan

Email: rizwan.arshad@iub.edu.pk

Muhammad Ibrahim Arshad

MS Scholar, National College of Business Administration \& Economics

Bahawalpur Campus, Pakistan

Muhammad Fahad Anwar

MS Scholar

MS Scholar, National College of Business Administration \& Economics Bahawalpur Campus, Pakistan

Accepted: September 13, 2013 DOI: 10.5296/jpag.v3i3.6219

\begin{abstract}
Nowadays, human resource is considered to be the most important asset of any organization. In order to get the efficient and effective results from human resource and to make them feel satisfied at their respective jobs, employee motivation is compulsory. An active and effective Corporate Social Responsibility (CSR) Division and Rewards System of an organization play significant role in motivating employees The current study examines the relationship between employee's motivation and job satisfaction with respect to Rewards (Both Intrinsic \& Extrinsic) and CSR (Internal \& External). Employees of banks and few organizations of Bahawalpur were taken as sample of the study. An already developed questionnaire was used
\end{abstract}


for data collection. 184 questionnaires were distributed. The data was analyzed using regression analysis. All findings were checked at 0.05 level of significance. The result concludes that there is a significant impact of External CSR on employee motivation while Internal CSR has an insignificant impact on employee motivation. Similarly, there is a direct relation of extrinsic rewards and the employee's motivation. Interestingly, extrinsic rewards found an insignificant impact on employee motivation. However, Employee Motivation is directly related to job satisfaction. This study has got managerial importance in the context that it is not the extrinsic rewards always at all levels which motivate employees. This study gives a direction to the management of the organizations including banks the importance of intrinsic rewards and external CSR.

Keywords: Employee Motivation, Intrinsic Rewards, Extrinsic Rewards, Corporate Social Responsibility, Job Satisfaction.

\section{Introduction}

Today each and every organization of the worlds wants to be market competitive, successful and wish to get regular progress. The present era is totally aggressive and organizations despite of size, technology and market focus are facing employee maintenance challenges. To overcome these fetters a strong and positive relationship and bonding should be created and maintained between employees and their organizations. Human resource or employees of any organization are the most vital part so they need to be inclined and influenced towards tasks fulfillment. Organizations must plan different strategies to compete with the competitors and for increasing the performance of the organizations in order to achieve success. There are very few organizations who believe that the human resource and employees of any organization are its main assets which can lead them to success or to decline if not focused well. Hence we can assume that none of the organization can progress or achieve success unless and until, the employees of any organization contented with it, are not motivated for the tasks fulfillment and goals achievements and encouraged.

To increase effective job management amongst employees in organizations employee motivation is the best tool being used by managers. A motivated employee always strives to achieve the definite goals and objectives; therefore he/she directs its efforts in that direction. Rutherford (1990) reported that motivation formulates an organization more successful because motivated employees are always in search for improved practices to do a work, so it is important for organizations to encourage motivation of their employees. To realize employees that they will have to do their best work even in laborious and tough conditions is one of the employees most affirm and slimy challenges and this can only be made possible through motivating them. There are several theories of motivation discussed by the researchers in the past. These theories of motivation tell us how motivation may contact employee dedication in an organization.(1) Equity theory, (2) expectancy theory, and (3) job design model given their significance and reported importance on employee retention. 
According to equity theory employees are anxious not only with the absolute amount of rewards they receive for their hard work, but also with the relationship of this amount to what others receive. Based on one's inputs, such as exertion, knowledge, learning, and capability, one can compare outcomes such as salary levels, increases, appreciation and other factor. The expectancy theory of motivation is a theory elaborating the practice individuals use to make decisions on different behavioral alternatives. The motivational power for a behavior, deed, or duty is a purpose of three divergent perceptions: expectancy, instrumentality, and valence. Motivational power is the force indicating definite behavioral alternatives, which are optional when deciding among behavior options. Expectancy theory usually is one of most normally used theories of motivation in the office and supported by practical facts. Expectancy theory gives a common structure for assessing, interpreting, and evaluating employee behavior in learning, decision-making, attitude creation, and motivation. The task itself is key to employee motivation is the hypothetical approach based on this thinking. Specially, a tedious and boring job stifles motivation to execute well, whereas a demanding job increases motivation. Diversity, sovereignty, and decision authority are three ways of adding challenge to a job. There are the two ways of counting variety and challenge; these are Job improvement and job rotation.

Heslen and Ochoa observed that CSR absolutely influence employee turnover, employee contentment, retention, devotion and obligation, (Heslin and Ochoa, 2008; Aguilera et al., 2007), and, therefore, employers may be able to use the firm's CSR outline as a tool to increase employee motivation. CSR has established the larger concentration from the theorists as well as practitioners only in the last few decades because CSR is relatively a new management theme. On the other side if talk about rewards, these can be defined by two dimensions, extrinsic or intrinsic. Extrinsic rewards are substantial rewards and these rewards are to be given on job or duties executed by the employee, external rewards are defined in terms of salary/pay, incentives, bonuses, promotions, job security, etc. Intrinsic rewards are intangible rewards or emotional rewards include appreciation, congregation the new challenges, positive and caring attitude from employer, and job rotation after attaining the objective. Organizations claim that preferred performance can only be achieved efficiently and effectively, if employee gets logic of shared gain of organization as well as of himself, with the realization of that definite object or aim. An organization should cautiously set the reward system to assess the employee's routine at all levels and then rewarding them according to their job duties and tasks assigned to them, the role of organization is very sensitive while monitoring that equal and merit base reward system is being implemented or not and they are also responsible to see that either their employees are satisfied with the reward system and motivated by the job duties assigned to them or not.

The basic aim of this paper is to identify the relationship between different variables discussed above i.e. Intrinsic and Extrinsic Rewards and Corporate Social Responsibility (External \& Internal).The implication of the study will give an idea about comparative importance of extrinsic and intrinsic rewards and Corporate Social Responsibility on Employee Motivation with respect to job satisfaction. 


\section{Macrothink \\ Journal of Public Administration and Governance \\ ISSN 2161-7104 \\ 2013, Vol. 3, No. 3}

\section{Literature Review:}

\subsection{Internal CSR (employees related)}

Brammer in his research concludes that Internal CSR actions are connected to all the inner activities of the organization (Brammer et al., 2007). This style of CSR is also described in detail in the European Commission (2001) Green Paper "Promoting a European framework for corporate social responsibility". Human resources are measured very imperative internal stakeholder group and educational prose gives a variety of CSR activities for gathering employees' hope and desires. Longo et al. (2005) categorized employee-related CSR activities into various groups, for example one of the categories is "value classes" which produce the value for the company's employees and therefore, convince their different opportunities. Employee "value classes" narrate to progress of workers' skills, group fairness, physical condition and security at work, welfare and contentment of the staff, and value of work.

\section{$H_{1:}$ There is a direct relationship between Internal CSR and Employee Motivation.}

\subsection{External CSR (customer related)}

In European Commission's famous paper which was published in 2001, it has been explained that socially responsible organizations are likely to offer products and services in a professional, moral and environmentally friendly way (European Commission, 2001). Clients in need of excellence of the products and services not only related with the product itself but also to the association with the organization which provides a method of complaints, suggestions and proposals. Additionally, customers favor the products that are shaped in agreement with socially liable criteria (Longo et al., 2005). Hence CSR actions have a considerable contact on customer-related outcomes and attitudes toward that organization action and its products.

\section{$H_{2:}$ There is a direct relationship between External CSR and Employee Motivation.}

\subsection{External CSR (local communities related)}

The literature examination tells that CSR activities toward local communities cover charitable actions for example aid activities, such as participating as donor in local sports, culture or arts proceedings. Organizations are considered as socially responsible if they create infrastructural investments in roads, water systems, schools or hospitals (Aguilera et al., 2007); Papasolomou-Doukakis suggested that organizations should initiate society improvement actions and promote their staff members to take part in community projects (Papasolomou-Doukakis et al., 2005); while European Commission suggested that 
organization should take part in small charity activities like aid poor children, sick or the handicapped or the ethnic minorities, for example hire socially expelled people (European Commission, 2001; Ligeti and Oravecz, 2009); Graafland also enforce the need of grant economic hold to social and other non-commercial community projects in order to play its role in the community development (Graafland and van de Van, 2006). All these CSR initiatives show the way to formation of additional value not only to the community but to the organization also.

\section{$H_{3:}$ There is a direct relationship between External CSR and Employee Motivation.}

\subsection{Extrinsic Rewards}

Monetary rewards are permissible obligations in the service connection and are serious incentives to magnetize and save employees. According to standard classification by Porter and Lawler (1968) that they have distinguished between intrinsic and extrinsic rewards quite clearly and categorically although both are related to each other and both are necessary. Porter and Lawler defined intrinsic rewards as the contentment that a person gets from doing the job and extrinsic rewards as real remuneration obtained as a result of doing the job, such as pay and promotions. According to Weatherly, rewards can be categorized as either financial or non-financial. Financial rewards submit to touchable, tangible or real items, such as pay, bonuses, promotions and proper recognitions, at the same time non-financial rewards are non-tangible and can be comprised as admire and individual recognitions (Weatherly, 2002). Chen et al. (1999) and Weatherly (2002) fall out that financial, as well as some non-financial rewards, can be measured extrinsic rewards.

\section{$H_{4:}$ There is a direct relationship between Extrinsic Rewards and Employee Motivation.}

\subsection{Intrinsic Rewards}

Porter \& Lawler together suggested that intrinsic rewards are the fundamental rewards which are inbuilt and inherent to the nature of the job, therefore intrinsic rewards can be chosen as the constructive emotional gratifications that a person gets from his or her hard work at job (Porter \& Lawler, 1968). They can as a result be equated to what Kallerberg (1977) termed as intrinsic job satisfaction. Intrinsic job satisfaction has been associated to various professional and administrative outcomes for instance motivation, affective commitment, preservation and organizational usefulness (Kallerberg, 1977; Selden \& Brewer, 2000).

\section{$\mathrm{H}_{5}:$ There is a direct relationship between Intrinsic Rewards and Employee Motivation.}




\subsection{Employee Motivation}

Humans all around the globe either in countries, cities, towns or in societies connect in work; still, what work means may fluctuate based on positive cultural distinctiveness. Such as applying Hofstede's model of cultural magnitude (Hofstede \& Hofstede, 2005), people from cultures of upper uncertainty evasion are motivated by work that give them job safety, whereas those from lower uncertainty evasion are extra involved in a fast track career and they have a chance for quick development and promotion. Deresky in his research work says that those People are expected to be more motivated by the upholding of a visibly demarked supervisor-assistant association who are from superior power distance while those are more motivated by the same relations with peers and managers, these people are from lesser power distance. Similarly he further ads that people from a more distinctive culture may be more motivated by opportunities for their personal progress and independence, while people from a more collectivistic culture may be more motivated by group support and participation (Deresky, 2006).

Obviously, work is attached to the idea of motivation. What motivates people to work. According to Maslow's Hierarchy of Needs model (Maslow, 1968), people have five stages of needs to be completed at every step in order to be motivated to go for next stage. These stages are: fundamental or physiological needs, security or protection needs, societal needs, esteem needs and self-actualization needs. For that reason, people work to struggle to accomplish these needs. For example to achieve first two levels of Maslow's hierarchy is, people work to get earnings to be able to have fundamental requirements for example food and have a place to live. People will work to have a life full of security and safety, knowing that at the end of each month they will receive their salary that will allow them to live as steadily as before. After achieving first two stages some people may get pleasure from working because it gives them a societal atmosphere where they could set of contacts and deal with other people. In this manner, their social needs are satisfied. People's esteem wishes may be rewarded when they receive value and appreciation for their work; that is related more to our intrinsic rewards portion which we discussed above and for some very lucky people, their self-actualization needs may be met by them when the doing work they really enjoy.

\subsection{Job Satisfaction}

Job satisfaction is a result of an employee's inside story of how well his job provides those things that are supposed to be considered as significant. Locke has cleared that enjoyable or optimistic emotional condition are the subsequent keys for the evaluation of one's job or job knowledge (Locke, 1976). While on the other hand Moser enforces the significance of Job satisfaction in a manner that he says in the absence of job satisfaction lethargy and reduced organizational commitment may occur (Moser, 1997). Rusbultet gave a comparison between satisfied and dissatisfied employees that a discontented or dissatisfied employee is more likely to give up their jobs in contrast with satisfied employees (Rusbultet al, 1988). It is therefore profession motivation can also be linked with job satisfaction. In disappointing and 


\section{Macrothink}

disturbing conditions organizations can relate Job satisfaction positively to the choice of their employee to adjust to shifting conditions. It encompasses convivial to job and managerial changes keep on working rather than quitting. As a result, those who reports enjoying their jobs are predictable to have strong career motivation or vice versa. In the results of prior research on career motivation, there are recommendations for a strong and positive relationship between the components of career motivation; affective organizational commitment and job satisfaction are evident. Accordingly we develop the following hypothesis.

$H_{6:}$ There is a direct relationship between Employee Motivation and Job Satisfaction.

\section{Conceptual Framework/Research Model:}

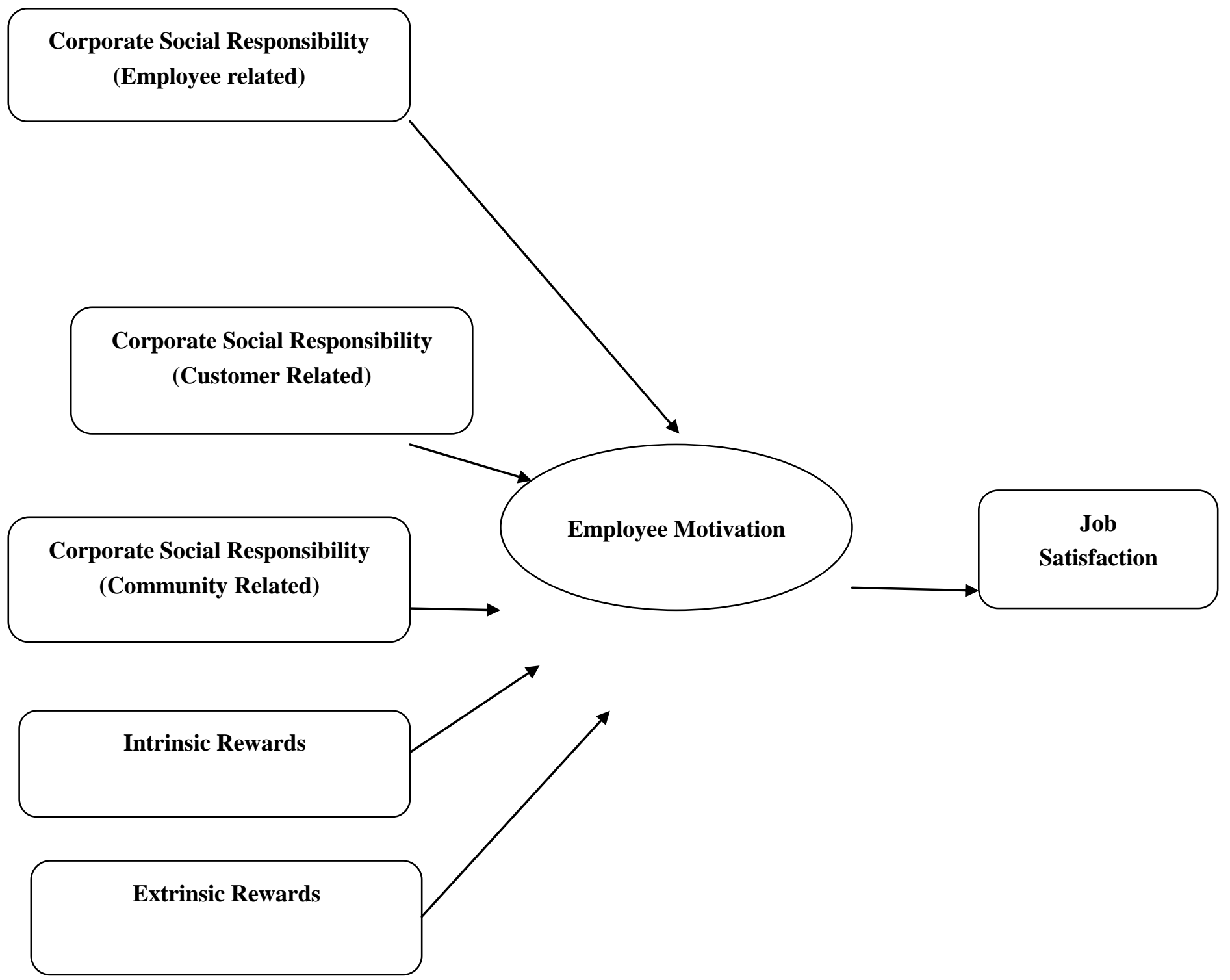




\section{Ml Macrothink}

\section{Research Methodology:}

As this study is conducted to see the impact of Employee Motivation on Job satisfaction with respect to independent variables such as Corporate Social Responsibility CSR (External \& Internal) and Rewards (Intrinsic \& Extrinsic). This research is conducted in Bahawalpur City. The population of the research is full time working employees of different banks and of different organizations other than banks.

\subsection{Sample \& Data Collection}

In order to get the data to see the impact of independent variables on dependent variable i.e Employee Motivation and further the impact of Employee Motivation on Job Satisfaction, a questionnaire technique will be used. The data will be collected from a reasonable sample of respondents from different banks and different private organizations locating their Branches/Offices in Bahawalpur.

\subsection{Research Instrument/ Scale}

An already published and developed scale/ questionnaire consisting of 23 items is used as research instrument to measure three independent variables which are further categorized into five sub dimensions such as corporate social responsibility categorized into internal CSR for Employees and external CSR for customers \& communities and Rewards has been categorized into Extrinsic such as pay, bonus, incentives etc and Intrinsic such as recognition, appreciation, authority etc.

The questionnaire contains two sections. Section 1 includes personal and demographic variables such as respondent's gender, age, income, and education. Section 2 contains all variables that are important in the current study. These variables are Employee Motivation, CSR (Employees), CSR (Customers), CSR (Communities), Rewards (Intrinsic) and Rewards (Extrinsic)

The scale of the study of different variables used is given below.

Table 1: Scale and different variables.

\begin{tabular}{|l|l|l|l|}
\hline $\begin{array}{l}\text { Sr. } \\
\#\end{array}$ & Variable & Items/ Question & Reference \\
\hline 1 & Employee & $\begin{array}{l}1-\text { I feel a sense of personal satisfaction when } \\
\text { I do }\end{array}$ & Deresky, 2006 \\
\hline
\end{tabular}




\begin{tabular}{|c|c|c|c|}
\hline & Motivation & $\begin{array}{l}\text { my job well. } \\
\text { 2- I feel pride in doing my job as well as I } \\
\text { accept } \\
\text { challenging tasks. } \\
\text { 3-I like to look back at a day's work with a } \\
\text { sense } \\
\text { either a job done well or not. }\end{array}$ & \\
\hline 2 & $\begin{array}{l}\text { Internal CSR } \\
\text { (Employees) }\end{array}$ & $\begin{array}{l}\text { 1-My organization applies equitable wage } \\
\text { system. } \\
\text { 2-My organization tries to improve } \\
\text { psychological } \\
\text { climate at workplace. } \\
\text { 3-My organization keeps an open, honest and } \\
\text { flexible communication with employees. } \\
\text { 4-My organization Involves employees into } \\
\text { decisions-making process. }\end{array}$ & $\begin{array}{l}\text { Aguilera et al., } \\
2007\end{array}$ \\
\hline 3 & $\begin{array}{l}\text { External CSR } \\
\text { (Customers) }\end{array}$ & $\begin{array}{l}\text { 1-My organization implements a procedure } \\
\text { to } \\
\text { handle consumers' complaints. } \\
\text { 2-My organization provides truthful and } \\
\text { honest } \\
\text { information to the consumers. } \\
\text { 3-My organization avoids false and } \\
\text { misleading } \\
\text { advertising or sales promotions that use } \\
\text { deception or manipulation. }\end{array}$ & $\begin{array}{l}\text { Aguilera et al., } \\
2007\end{array}$ \\
\hline 4 & External CSR & $\begin{array}{l}\text { 1-My organization supports local sport, } \\
\text { cultural } \\
\text { or other community activities and }\end{array}$ & $\begin{array}{l}\text { Aguilera et al., } \\
2007\end{array}$ \\
\hline
\end{tabular}




\begin{tabular}{|c|c|c|c|}
\hline & $\begin{array}{l}\text { (Local } \\
\text { Communities) }\end{array}$ & $\begin{array}{l}\text { projects. } \\
\text { 2-My organization donates money to local } \\
\text { charities. } \\
\text { 3-My organization invests in the } \\
\text { community's } \\
\text { development (i.e. investments in roads, } \\
\text { schools } \\
\text { or hospitals) }\end{array}$ & \\
\hline 5 & $\begin{array}{l}\text { Extrinsic } \\
\text { Rewards }\end{array}$ & $\begin{array}{l}\text { 1-I am satisfied with the existing salary } \\
\text { structure } \\
\text { of the organization. } \\
\text { 2-My salary structure is revised annually. } \\
\text { 3-I get salary according to the duties I } \\
\text { perform } \\
\text { on the job. } \\
\text { 4-I get annual cash awards for my job } \\
\text { performance. }\end{array}$ & Deresky, 2006 \\
\hline 6 & Intrinsic Rewards & $\begin{array}{l}\text { 1-I have the authority to correct customer } \\
\text { problems when they occur. } \\
\text { 2- I feel happy with the recognition and } \\
\text { rewards } \\
\text { for my outstanding work and } \\
\text { contribution. } \\
\text { 3- I get appreciation from my boss for any } \\
\text { extra } \\
\text { work which I do. }\end{array}$ & Deresky, 2006 \\
\hline 7 & Job Satisfaction & $\begin{array}{l}\text { 1-Overall, I am pleased with my work. } \\
\text { 2- My current work situation is not a major } \\
\text { source of frustration in my life. } \\
\text { 3- If I had it to do it all over again, I'd still }\end{array}$ & Moser, 1997 \\
\hline
\end{tabular}




\begin{tabular}{|l|l|l|l|}
\hline & choose to work where I do now & \\
\hline
\end{tabular}

\subsection{Procedure}

The questionnaire was distributed amongst 184 respondents in Bahawalpur. These respondents were selected from different banks and organizations. Before giving them questionnaire the purpose of the study and questions were explained to the respondents so that they can easily fill the questionnaire with relevant response. After data collection from these respondents all 184 questionnaire were coded and entered into SPSS Sheet for further analysis.

\subsection{Reliability Analysis}

Overall Cronbach's Alpha value was 0.786, which is acceptable as per standard value 0.50 by Nunnally and 0.60 by Moss (1998). The Cronbach's Alpha of each variable is given in the table shows that all 23 items were reliable and valid to measure the response of the respondents towards Employee Motivation.

Table 2: Reliability of Measurement Instrument

\begin{tabular}{|l|l|l|}
\hline Variable & No. of Items & Cronbach's Alpha \\
\hline Employee Motivation & 3 & .779 \\
\hline Internal CSR (Employees) & 4 & .779 \\
\hline External CSR (Customer) & 3 & .726 \\
\hline External CSR ( Community) & 3 & .395 \\
\hline Intrinsic Rewards & 3 & .647 \\
\hline Extrinsic Rewards & 4 & .719 \\
\hline Job Satisfaction & 3 & .734 \\
\hline TOTAL & 23 & Overall Value $=0.786$ \\
\hline
\end{tabular}




\section{Hypothesis Testing \& Analysis:}

\subsection{Profile of the respondents}

The demographic information of 184 respondents such as Gender, Age, Income, and Education is given in the table below.

Table 3: Profile of the respondent

\begin{tabular}{|c|c|c|c|}
\hline Variable & Category & Frequency & Percentage \\
\hline Gender & $\begin{array}{l}\text { Male } \\
\text { Female }\end{array}$ & $\begin{array}{l}113 \\
71\end{array}$ & $\begin{array}{l}61.4 \\
38.6\end{array}$ \\
\hline Age & $\begin{array}{l}\text { 20-25 Years } \\
\text { 25-30 Years } \\
\text { 30-35 Years } \\
\text { 35-40 Years } \\
40 \text { Years \& Above }\end{array}$ & $\begin{array}{l}53 \\
77 \\
29 \\
17 \\
8\end{array}$ & $\begin{array}{l}28.8 \\
41.8 \\
15.8 \\
9.2 \\
4.3\end{array}$ \\
\hline Income ( Monthly) & $\begin{array}{l}\text { below } 20,000 \\
20,000-30,000 \\
30,000-40,000 \\
40,000-50,000 \\
50,000 \& \text { Above }\end{array}$ & $\begin{array}{l}37 \\
65 \\
37 \\
28 \\
17\end{array}$ & $\begin{array}{l}20.1 \\
35.3 \\
20.1 \\
15.2 \\
9.2\end{array}$ \\
\hline Education & $\begin{array}{l}\text { Matriculation } \\
\text { Inter } \\
\text { Bachelor } \\
\text { Masters } \\
\text { M.Phil } \\
\text { Ph.D }\end{array}$ & $\begin{array}{l}8 \\
9 \\
58 \\
99 \\
9 \\
1\end{array}$ & $\begin{array}{l}4.3 \\
4.9 \\
31.5 \\
53.8 \\
4.9 \\
0.5\end{array}$ \\
\hline TOTAL & & 184 & 100 \\
\hline
\end{tabular}




\subsection{Hypothesis Testing/ Hypothesis Results}

After regression analysis and according to the results of the study, Internal CSR (Employees related) has no significant impact on Employee Motivation with significant value $p=0.330$ (where as $\mathrm{p}$ must be $<0.05$ for a significant relation). Hence $\mathrm{H} 1$ does not prove as our $1^{\text {st }}$ Hypothesis.

However the external CSR for customer and local communities related both have been proven to be significant with Employee Motivation. The significant values for both External CSR are $p=0.000$ which shows the strong significant impact on Employee Motivation. The estimate value ( $\beta=0.398$ for CSR customer related \& $\beta=0.144$ for CSR community related) shows positive relation and 39\% \& 14\% impact on Employee Motivation respectively. Hence that proves $\mathrm{H} 2$ and $\mathrm{H} 3$ of our hypothesis the positive relation and significant impact of External CSR (Customer \& Community related) on Employee Motivation.

Interestingly, Extrinsic rewards could not get an impact on Employee Motivation, despite the fact that Extrinsic Rewards such as Pay, Bonuses, Incentives play a significant role in motivating employees at their work places according to past researches, but here we get significant value $\mathrm{p}=0.268$ which is more than the standard significant value $(\mathrm{p}<0.05)$ while on the other side Intrinsic Rewards such as appreciation, recognition got a significant impact on Employee Motivation. As per regression analysis $\mathrm{p}=.000$ shows the significance and $\beta=.058$ shows almost $6 \%$ positive impact of Intrinsic Rewards on Employee Motivation.

Similarly, Employee Motivation has also got a significant impact on job satisfaction. The $\mathrm{p}=$ 0.000 shows strong significance and $\beta=0.277$ shows $27 \%$ positive impact of Employee Motivation on Job Satisfaction.

Table 4 summarizes the regression results of the study.

Table 4: Regression results.

\begin{tabular}{|l|l|l|l|l|l|l|}
\hline Hypothesis & Model Variables & Estimate & S.E & C.R & P & Results \\
\hline H1 & Internal q̧SR(Emp) & & & & & \\
\hline H2 & $\begin{array}{l}\text { Employee } \\
\text { Motivation }\end{array}$ & .045 & .046 & .977 & .330 & Not Supported \\
\hline & $\begin{array}{l}\text { External } \mathbb{C S R}(\mathrm{Cus}) \\
\text { Employee } \\
\text { Motivation }\end{array}$ & .398 & .065 & 6.122 & .000 & Supported \\
\hline
\end{tabular}




\begin{tabular}{|c|c|c|c|c|c|c|}
\hline H3 & $\begin{array}{l}\text { External } \mathbb{C S R}(\mathrm{Com}) \\
\text { Employee } \\
\text { Motivation }\end{array}$ & .144 & .039 & 3.722 & .000 & Supported \\
\hline $\mathrm{H} 4$ & $\begin{array}{l}\text { Extrinsic } \mathbb{R} \text { ewards } \\
\text { Employee } \\
\text { Motivation }\end{array}$ & .058 & .052 & 1.111 & .268 & Not Supported \\
\hline H5 & $\begin{array}{l}\text { Intrinsic } \underset{\checkmark}{\mathbb{R} e w a r d s} \\
\text { Employee } \\
\text { Motivation }\end{array}$ & .277 & .052 & 5.333 & .000 & Supported \\
\hline H6 & $\begin{array}{l}\text { Employee } \\
\text { Motivation } \\
\downarrow \\
\text { Job Satisfaction }\end{array}$ & .640 & .153 & 4.178 & .000 & Supported \\
\hline
\end{tabular}




\section{Macrothink}

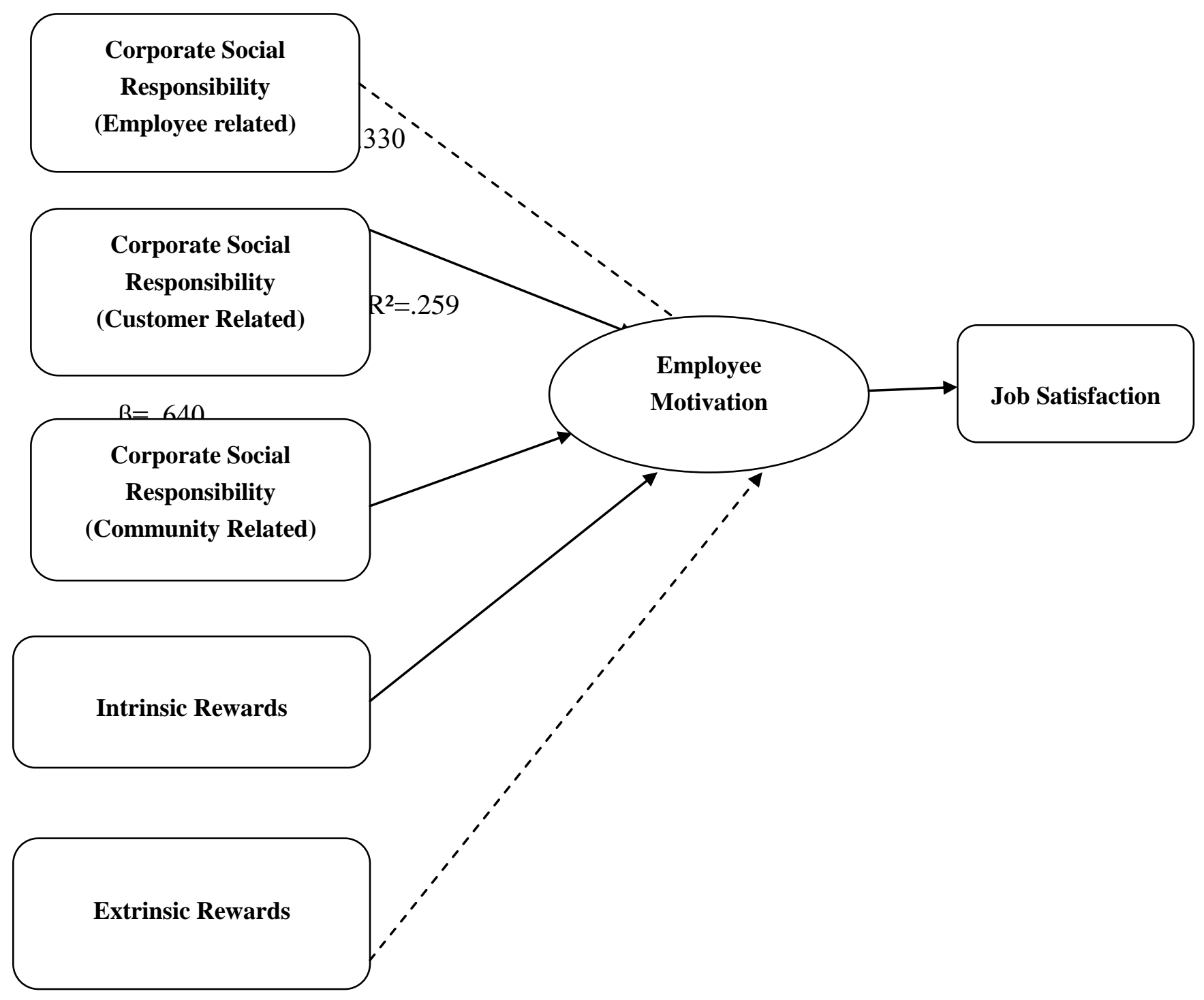

\section{Discussion:}

The basic aim of the study was to see the level of motivation and job satisfaction in employees in different organizations. Previous studies suggest that in order to keep employees motivated, organizations need to understand the mental and physical capabilities of their employees and to make their working conditions, infrastructure and job duties according to the comfort level of their staff and utilization of his/her capabilities to the optimum level. The results of analysis allow us to accept and reject few of the hypotheses we developed in the beginnings on the basis of past researches.

The Internal CSR (Employee related) has no significant impact on Employee Motivation; it does not support our $1^{\text {st }}$ hypothesis, which shows that either employee do not give importance to the CSR related to their own values in the organization or they are not satisfied with their organization's efforts towards value addition to their stakeholders. However the impact of 
External CSR (Customer \& Community Related) on Employee Motivation is significant and positive shows the strong binding and commitment of organization towards their external customers as well as their active role in the betterment of the society. These organizations do whatever they claim for the betterment of the society which plays a significant role in the motivational level of employees. Thus, External CSR (Customer \& Community related) have a positive relation with employee motivation, proves $\mathrm{H} 2$ and $\mathrm{H} 3$ hypotheses.

Carraher et al (2006) advices if you want to retain the high performers in the organization than there should be an effective reward system and rewards should be related to their productivity. Surprisingly, the result of our study is opposite as there is no significant relation between extrinsic rewards and employee motivation. This result can be accepted in two ways that either the data has been taken from those employees who are at the extreme level of their perks and benefits in their respective organizations where the tangible rewards do not matter to them or the respondents are more in crave of intrinsic rewards in terms of appreciation, recognition, and job authority etc to remain motivated in their organizations, because our next hypothesis has been proven strongly significant. After analysis the result shows a positive and significant relation between intrinsic rewards and employee motivation. Thus, in our hypotheses H4 is not supported but H5 is strongly supported.

Researchers have proved that employee motivation is directly proportional to job satisfaction and this has been proved in our study as well. The regression analysis of H6 concludes that employee motivation has a significant and positive relation with job satisfaction. The more one will be motivated the more he/she will be satisfied with his/her job in the organization.

\section{Recommendations:}

On the basis of the results of the study some recommendations for management practices can be provided. First, external CSR positively influence employee motivation. Therefore, executives can exercise this information in order to resolve practical problem by giving the precedence to CSR activities to get better organizations' image and standing, the socially responsible behavior of an organization management may add to the corporate status development, convey positive effects related to its stakeholders and add to competitive advantage. Moreover, employees should be more dynamically involved in CSR activities undertaken by the organization. This would not only make possible the stream of information but would let the employees to sense like a part of their organization and more psychologically engage into CSR initiatives and feel stronger association with the organization.

Secondly, it has been proved now that an effective an employee friendly reward system always play important role in motivating employees. If we see the results of our study it is slightly different from the current trend that shows the importance of intrinsic rewards yet one cannot deny the importance of extrinsic rewards such as pay, bonus, and fringe benefits. The results of our study reveals that organizations must apply a proper reward system where intrinsic rewards such as appreciation, recognition, authority, decision powers should be given equal weight age besides extrinsic rewards. Because employees need both the rewards in order to be satisfied and motivated at their work places. 


\section{Limitations and Future Research:}

There were certain limitations during the study which are to be taken into account for future researches. This study was limited to one city Bahawalpur under investigation; therefore, further research may be extended to other big cities of Pakistan like Karachi, Lahore, Islamabad, Faisalabad, and Peshawar. The sample size was too small to investigate; there must be a bigger sample size in order to get more specific results. Also the data was taken from the respondents during their busy working hours which may influence the results by the different hasty responses of the respondents. Since the aim of the research was to examine the impact of CSR and Reward System on employee motivation, questionnaire method was the best choice. However, it would be interesting to interview head managers and find out their attitude and experience about CSR and Reward System and its impact on employee motivation.

\section{References:}

1-Aguilera, R.V., Rupp, D.E., Williams, C.A. and Ganapathi, J. (2007), "Putting the S back in corporate social responsibility: a multi-level theory of social change in organizations", Academy of Management Review, Vol. 32 No. 3, pp. 836-63.

2-Bryman, A. (2008), Social Research Methods, 3rd ed., Oxford University Press, New York, NY.Campbell, J.L. (2007), "Why would corporations behave in socially responsible ways?

3-Brammer, S., Millington, A. and Rayton, B. (2007), "The contribution of corporate social responsibility to organizational commitment", International Journal of Human Resource Management, Vol. 18 No. 10, pp. 1701-19.

4-Carroll, A.B. (1991), "The pyramid of corporate social responsibility: toward the moral management of organizational stakeholders”, Business Horizons, Vol. 34 No. 4,pp. 39-48.

5-Campbell, J.L. (2007), "Why would corporations behave in socially responsible ways? An institutional theory of corporate social responsibility", Academy of Management Review, Vol. 32 No. 3, pp. 946-67.Chen, C.C., Ford, C.M., \& Farris, G.F. (1999).

6-Do rewards benefit the organization? The effects of reward types and the perceptions of diverse R\&D professionals. Transactions on Engineering Management, 46(1), 47-55.

7-Cochius, T. (2006), “Corporate social responsibility in Dutch SMEs: motivation and CSR stakeholders", thesis, Maastricht University, Maastricht.

8-Deresky, H. (2006). International management: Managing across borders and cultures (5th Ed.). Pearson/Prentice Hall.

9-European Commission (2001), "Promoting a European framework for corporate social responsibility”, Green Paper, European Commission, Brussels.

10-Graafland, J. and van de Van, B. (2006), "Strategic and moral motivation for corporate social responsibility”, Journal of Corporate Citizenship, Vol. 22, pp. 111-23. 
11-Heslin, P.A. and Ochoa, J.D. (2008), "Understanding and developing strategic corporate social responsibility”, Organizational Dynamics, Vol. 37 No. 2, pp. 125-44

12-Hofstede, G. \& Hofstede, G.J. (2005).Cultures and organizations: Software of the Mind, New York: McGraw-Hill USA James, H.S. (2004), "Why did you do that? An economic examination of the effect of extrinsic compensation on intrinsic motivation and performance", Revision of CORI Working Paper No. 2003-01.

13-Kallerberg, A.L. (1977). Work values and job rewards: A theory of job satisfaction. American Social Review, 42, 124-143. http://dx.doi.org/10.2307/2117735

14-Kaiser, H.F. (1970). A second-generation little giffy. Psychometrika, 35, 401-415. http://dx.doi.org/10.1007/BF02291817

15-Longo, M., Mura, M. and Bonoli, A. (2005), "Corporate social responsibility and corporate performance: the case of Italian SMEs", The International Journal of Effective Board Performance, Vol. 5 No. 4, pp. 28-42.

16-Ligeti, G. and Oravecz, A (2009), "CSR communication of corporate enterprises in Hungary",Journal of Business Ethics, Vol. 84 No. 2, pp. 137-49.

17-Locke, E. A. (1976). The nature and causes of job satisfaction. In M. D. Dunnette (Ed.), Handbook of industrial and organizational psychology

18-Maslow, A.H. (1968). Toward a psychology of being. New York: John Wiley \& Sons

19-Moser, K. (1997). Commitment in organizations. Psychologies, 41 (4), pp.160-170.

20-Nunnally, J.C. (1978), Psychometric Theory, McGraw-Hill, New York, NY.

21-Porter, L.W., Lawler, E.E., 1968.Managerial Attitudes and Performance Irwin, Homewood, ILL.

22-Papasolomou-Doukakis, I., Krambia-Kapardis, M. and Katsioloudes, M. (2005), "Corporate social responsibility: the way forwards? Maybe not!", European Business Review, Vol. 17 No. 3,pp. 263-79.

23-Rutherford, D. G. (1990). Hotel Management and Operations. New York, NY: Van Nostrand Reinhold.

24-Selden, S.C., \& Brewer, G.A. (2000). Work motivation in the senior executive service: Testing the high performance cycle theory. Journal of Public Administration Research and Theory, 3, 531-550. http://dx.doi.org/10.1093/oxfordjournals.jpart.a024280

25-Weatherly, R.L. (2002). Effects of external rewards on internal motivation and job satisfaction. Master's thesis. Retrieved,From,http://etd.lib.ttu.edu/theses/available/etd 0731200831295017084509/unrestricted/31295017084509.pdf 